out when the rickety flat pelvis starts $I$ have made a large number of measurements of the pelves of normal children and compared them with the measurements of pelves of children with rickets. The pelvis of a child with rickets shows little outward signs of any abnormal measurements. In all nearly 150 pelves of normal healthy children of all ages from 1 to 14 years have been examined and the results tabulated.

With callipers as ordinarily used in midwifery the distances were measured between (1) the anterior superior spines of the iliac crest, (2) the iliac crests, (3) the trochanters, and (4) the external conjugate diameter. These measurements are easily made; they show that the pelvis of a normal child slowly and regularly increases in size.

The pelves of over 150 female children with rickets, at all ages from 1 to 14 years, were measured in the same way. On comparing the normal pelves with the rickety some very marked differences were apparent, the most noticeable being the relative smallness of the external conjugate in rickets. This difference becomes more marked as the children grow older; thus at the age of 5 years the external conjugate in normal children averaged 4.8 inches, and in rickety children of the same age only 4.1 inches. At the age of 13 years the external conjugate was 6 inches in normal children and only 4.9 inches in rickety children-a difference of over an inch.

Table giving the Measurements of Normal and Rickety Pelves of Children aged 1 to 14 years.

\begin{tabular}{|c|c|c|c|c|c|c|c|c|}
\hline \multirow{2}{*}{$\begin{array}{c}\text { Age } \\
\text { in } \\
\text { Years. }\end{array}$} & \multicolumn{4}{|c|}{ Normal. } & \multicolumn{4}{|c|}{ Rickety. } \\
\hline & I.S. & I.C. & E.C. & Tr. & I.S. & I.C. & E.C. & Tr. \\
\hline 1 to $2 \ldots$ & 5.4 & 5.6 & 3.8 & 6.0 & 4.8 & 5.2 & 3.4 & 5.9 \\
\hline 2 to $3 \ldots$ & 5.8 & 6.0 & 3.8 & 6.3 & 5.2 & 5.5 & 3.4 & 6.1 \\
\hline 3 to $4 \ldots$ & 5.8 & 6.1 & 4.0 & 6.9 & 5.3 & 5.9 & 3.5 & 6.5 \\
\hline 4 to $5 \ldots$ & 6.0 & 6.5 & 4.0 & 7.0 & 5.8 & 6.2 & 3.8 & 6.6 \\
\hline 5 to $6 \ldots$ & 7.0 & 7.5 & 4.8 & 7.9 & 6.0 & 6.5 & 4.1 & 7.2 \\
\hline 6 to $7 \ldots$ & 7.0 & 7.5 & 4.85 & 8.0 & 6.2 & 6.7 & 4.1 & 7.15 \\
\hline 7 to $8 \ldots$ & 7.1 & 7.8 & 5.1 & 8.0 & 7.0 & 7.5 & 4.8 & 8.2 \\
\hline 8 to $9 \ldots$ & $7.1^{\circ}$ & 7.6 & 5.4 & 8.0 & 6.6 & 7.0 & 4.6 & 7.4 \\
\hline 9 to $10 \ldots$ & 7.25 & 7.5 & 5.5 & 8.55 & 7.75 & 8.5 & 5.0 & 8.5 \\
\hline 10 to $11 \ldots$ & 7.75 & 8.25 & 5.75 & 8.75 & 7.8 & 8.8 & 5.0 & 9.3 \\
\hline 11 to $12 \ldots$ & 7.75 & 8.25 & 5.75 & 8.75 & 7.8 & 8.5 & 5.0 & 8.9 \\
\hline 12 to $13 \ldots$ & 8.0 & 8.5 & 6.0 & 9.0 & 7.8 & 8.0 & 4.9 & 9.7 \\
\hline 13 to $14 \ldots$ & 8.5 & 9.0 & 6.5 & 9.6 & 8.2 & 8.2 & 5.4 & 9.5 \\
\hline
\end{tabular}

I.S. = Measurement between the iliac spines. I.C. = Measuremen between the iliac crests. E.C. = External conjugate. Tr. $=$ Measuremen

This diminution of the external conjugate is the marked feature of the rickety flat pelves of women and the cause of so much difficulty at childbirth. The pelvis, including the sacrum and iliac bones, like the other bones, are softened in rickets and liable to bend under strain. The chief cause of the diminished external conjugate is that the sacrum is bent and displaced forwards by the body weight. The promontory of the sacrum is carried in this way nearer the symphysis. The smallness of the external conjugate in older children shows this clearly, for it is relatively much smaller than at the earlier ages. As the child grows older and heavier the weight pushes the sacrum downwards and forwards towards the symphysis. This diminution of the external conjugate even in early life proves that it is the rickets of early child. hood which is the origin of the typical flat pelves of women.

The other measurements, interspinous and intercristal, are not markedly less in rickets than in the normal. After the age of about 9 years the interspinous measurement becomes slightly larger in rickets than in the normal. This is to be explained by the fact that the body weight presses out the iliac crests, so that the iliac fossae look forwards instead of forwards and inwards:

In the riclsety flat pelves of adults the measurement between the spines approximates closely to that between the crests, owing to the pressing outwards of the spines by the body weight. This is not so in children until near puberty, when the body weight increases so much. The measurement between the trochanters is greater in rickety than in normal children, especially after the age of 7 years. This is no doubt due for the most part to coxa vara-a common condition in rickets-but partly to the thickened great trochanter. The average height of the rickety children measured was less than the normal height for age, owing to their lack of development, lordosis, and the curvature of the legs.

The conclusion to be drawn from these measurements is that rickets in early childhood, and continuing during child. hood, is the cause of the rickety flat pelves of adult women, and as long as rickets remains prevalent so will there be difficulty and danger with childbirth in a number of women, especially among the populations of large towns.

At present rickets shows little dininution, and the large amount which occurred during the war and since will con. tinue to leave its mark in future years, when these children get married. It is to be hoped that the large amount of work which is being carried out all over the country on the cause and treatment of rickets will diminish its frequency in the future.

I am much indebted to Dr. J. W. Bride for his help and co-operation in this short article.

\section{AN OUTBREAK OF DIPHTHERIA DUE TO INFECTED MILK.}

\section{BY}

\section{A. E. PORTER, M.D., D.P.H.,}

MEDICAL OFFICER OF HEALTH FOR THE BOROUGH AND RURAL OF HEALTE FOR THE BO
DISTRICT OF REIGATE.

MILK-BORNe epidemics of infectious diseases are seldom without points of interest, and a small outbreak of diph. theria, which occurred in the borough of Reigate during December, 1921, and January, 1922, was no exception.

Diphtheria had been somewhat unusually prevalent during 1921, sixty-five cases being notified in a population of slightly under 29,C00. Only nine of the patients were above the age of 15 ; most of them were members of working-class families, and, apart from two small groups, where school infection was prominent, the cases occurred at appreciable intervals, with no obvious connexion one with anotler.

Between January 4th and 17th, 1922, however, I received notifications of fourteen cases of diphtheria, occurring in thirteen different houses, scattered over various parts of the borough (which has an area of 6,000 acres), every house being supplied with milk from one retailer; there was no other factor in common. Eight of the patients were adults, and nine of the houses were large residences, while two of the patients living in cottages were daily maids in large houses supplied by tle same retailer. The attacks among the fourteen patients ranged from December 22nd, 1921, to January 14th, 1922. Six of the fourteen patients, were males.

Five individuals were attacked on January 4th, three on January 6th, two on January 7th, and one each on Decem. ber 22nd and January 1st, 8th, and 14th. A further case, a boy of 6 , who was attacked on December 25th and notified on December 27 th, also had milk from the same retailer.

Inquiries at the houses showed that all the patients con sumed the milk as delivered, though in some of the larger residences milk intended for the children was boiled as a matter of routine. None of these children were attacked.

During January four further cases of diphtheria occurred; one of these, consuming milk from the suspected retailer, was infected whilst in London; the remainder were supplied from other sources. Among the cases notified earlier in December and those notified after January 17 th there was no reason for attaching suspicion to any milk supply. This particular outbreak may therefore be considered to include fifteen cases in fourteen different dwellings.

I began to suspect that milk was the source of infection about January 9 th, and on January 10 th $I$ wrote to all the general practitioners suggesting that as opportunity offered they should recommend their patients to boil all milk delivered, and $I$ issued a letter in the local weekly newspaper on January 13th adrocating the same precaution. From a purely scientific point of view this may have been regrettable, but the measure was justified by subsequent occurrences.

The implicated retailer sends out about 450 gallons a day, and supplies some 2,100 houses. The milk is derived from thirteen different farms, situated in Surrey, Sussex, and Kent. 
Milk from each farm is distributed so far as is practicable to one particular round, and it was possible, therefore, to ascertain the farm from which all but one of the infected houses obtained milk. I fully expected that one farm would be implicated especially; but this was not the case, since no less than five different farms were concerned. If these are indicated by the letters A, B, C, D, and E, A supplied three houses, B one, $\mathrm{C}$ three, $\mathrm{D}$ three, and $\mathbf{E}$ three, whilst the fourteenth house had milk occasionally from $\mathrm{A}$, occasionally from C, and occasionally from $D$.

Each round had a different roundsman, and infection during delivery appeared, therefore, to be out of the question. Infection at the receiving station seemed a possible solution. On inquiry I found that, as the farm churns arrived, the milk was emptied into a measuring drum, cooled (if this had not been effected at the farm), and passed through a strainer into the roundsmen's churns, the strainers consisting of four thicknesses of muslin over a metal frame. All churns and other utensils were thoroughly sterilized by steam after use. Only two men handled the milk at the dépôt. On January 11th I took swabs from the throats and noses of both, and obtained negative bacteriological results. Neither of them had recently suffered from any kind of illness, they had no families, and there had been no illness in their homes.

It is obvious, however, that if the milk from one of the farms were infected, the muslin strainer would be likely to retain some of the bacilli, which might readily infect milk from other farms when passed through the strainer subsequently, and this appeared to be the most likely solution of the problem, since it is almost inconceivable that five farms should be infected simultaneously.

Farms A, C, and D are situated in Reigate rural district, $B$ in an adjoining rural district, and $\mathbf{E}$ in Kent. Inquiries at these farms yielded no information of illness resembling diph. theria among the farm hands or their families. Farms $\mathrm{C}$ and $D$ are situated in a parish where there had been an outbreak of diphtheria, comprising fifteen cases in thirteen families between August 29th and December 22nd, 1921, with four further carriers in infected houses. It had been an unusually troublesome outbreak to deal with, owing principally to a concurrent epidemic of influenza, and to the omission to obtain medical advice in several instances. Although I had succeeded in identifying several "missed" cases, as well as a number of healthy carriers, I could not satisfy myself that all important sources of infection had been detected, and was left with the impression that further unrecognized attacks had occurred, probably among adults.

Early in November a schoolboy was removed to hospital whose eldest brother was a cowman at $D$ farm. The cow. man and all the other school children were examined bac. teriologically, and the cowman and one girl were found to be carriers. Both were removed to hospital on November 6th, and were not discharged until February, 1922. The only other inmate of this house concerned with the farm was the father, who was bailiff. He had nothing to do with the cows, and was not examined. On January 12 th I heard that the head cowman had been laid up with rheumatic fever since December 28th, and that the bailiff was doing his work. I swabbed his throat and nose that day, and obtained negative results. Negative results were also obtained at the Lister Institute a fortnight later. No cases had occurred in the neighbourhood of $\mathrm{C}$ farm.

So far, therefore, there was no evidence to incriminate D farm, although it appeared to be the most likely source of the Reigate outbreak. 'The milk from this farm is one of the earliest to arrive at the Reigate dépôt, and therefore is one of the first to pass through the strainer. I arranged that separate strainers shoula be used for A, C, and D farms on January 12th, and sent these to the Lister Institute for bacteriological examination, intending to await the report before taking any further action. As the public had largely adopted my suggestion of boiling their milk, there was little risk of a spread of infection. The examination was com. pleted on January $25 \mathrm{th}$, both cultural and inoculation investigations being made; diphtheroids were isolated, but no true diphtheria bacilli were found.

The problem, however, was solved on January 22nd, when another cowman, son of the head cowman from D farm, was removed to hospital with diphtheria. His faucial attack began on January 19th, but on admission to hospital he was found to have sores on both arms which had existed for nearly six weclis. Unfortunately energetic treatment was successfully applied before I had an opportunity of making a bacteriological examination, but I was assured that the sores had the appearance typical of diphtheritic infection of the skin. The inquiries made at each of the farms A, C, and D had included the existence or otherwise of such sores, but their presence had been denied in this instance. The farm supplied about seventy gallons a day, milking being carried out by four cowmen. In the course of the next few days I took swabs from the throats and noses of nineteen persons on the farm, including all the remaining cowmen and other farm hands and their families. Seven carriers were found, one being the head cowman, who had been laid up with rheumatic fever, as already mentioned, the remainder being children, three of them in cowmen's families. All were removed to hospital. I had the teats and udders of all the cows, thirty-three in number, examined. On the udder of one was a superficial ulcer, apparently of traumatic origin. A swab from it yielded a negative result. Another cow had a cyst in a dry quarter. All the remaining cows were healthy.

On January 23 rd the milk from $D$ farm was withdrawn from the retailer's supply, was pasteurized, and made into butter. Apart from a few gallons consumed by the families employed on the farm all the milk is sent into Reigate. It is curious that none of the children on the farm contracted diphtheria; but possibly some of the carriers were accounted for in this way.

Owing to the impossibility of confirming the nature of the sores on the young cowman's arms bacteriologically it cannot be asserted definitely that he was the actual infecting agent, though this is by far the most likely explanation. The illness which laid up his father was undoubtedly rheumatic ferer, which may or may not have been associated with an attack of diphtheria; but in any case he was not engaged in milking at the time the outbreak was at its height. Although carriers were found in the family of another cowman he himself appeared to be free.

This outbreak differed from the usual textbook description in the absence of any marked suddenness in its appearance, and in the occurrence of only one instance of multiple attacks in the same household. It is also somewhat remarkable that so few cases should have occurred among the 8,000 or more consumers of the supply. This, however, may largely be accounted for by the practice of allocating the milk from each farm to a particular round.

The character of the attaclis was mild. There were no deaths, but in many instances the infective period was a very long one.

\section{THE ACTION OF CARBON TETRACHLORIDE ON THE LIVER.}

BY

J. F. DOCHERTY, B.A., M.B.Toronto,

DIRECTOR OF ANCHYLOSTOMLASIS CAMPAIGNS FOR CEYLON; AND

E. BURGESS,

ACTING DIRECTOR OF BAOTERIOLOGICAL INSTITETE.

In view of the report by Dr. W. G. Smillie and Dr. S. Pessoa $^{1}$ to tho effect that carbon tetrachloride in small doses produced a definite fatty degeneration of the liver and kidneys of dogs it.was deemed advisable, before using this drug generally in Ceylon as a vermifuge, to ascertain whether or not these losions were produced in man, using the maximum dose of $5 \mathrm{c.cm}$. as defined by Hampton and Nicholls. ${ }^{2}$ Lsach ${ }^{3}$ reports from autopsy that no macroscopical change was noted in the liver or kidney following a $12 \mathrm{c.cm}$. dose; apparently no microscopical examination was made.

With the approval of the superintendent of prisons and the personal consent of the prisoners, two condemned men were treated with $5 \mathrm{c.cm}$. of carbon tetrachloride and one with $8 \mathrm{cccm}$. in two doses of 5 and $3 \mathrm{c.cm}$. The anthelmintic was given on an empty stomach, followed by tiffin of rice at the hours mentioned, and, as indicated, No. 1 received a postpurge of $1 \mathrm{oz}$. of saturated magnesium sulphate solution three and a half hours later; No. 2 received the same eight hours after treatment; while No. 3 received none, having vomited the first and declined the second.

Autopsies were performed on dates mentioned, when the entire intestinal tract from the pylorus to, but not including, the rectum was remored after being double ligatured in 